\title{
Ultraviolet light-emitting diode irradiation-induced cell death in HL-60 human leukemia cells in vitro
}

\author{
DONG XIE ${ }^{1}$, YAN SUN ${ }^{1}$, LINGZHEN WANG $^{1}$, XIAOLING $\mathrm{LI}^{2}$, \\ CHUANNONG ZANG ${ }^{3}$, YUNLAI ZHI ${ }^{4}$ and LIRONG SUN ${ }^{1}$ \\ ${ }^{1}$ Department of Pediatric Hematology, Affiliated Hospital of Qingdao University, Qingdao, Shandong 266003; \\ ${ }^{2}$ Department of Pediatrics, People's Hospital of Linyi, Linyi, Shandong 276000; \\ ${ }^{3}$ Department of Pediatrics, Central Hospital of Wendeng, Weihai, Shandong 264400; \\ ${ }^{4}$ Department of Pediatric Surgery, Affiliated Hospital of Qingdao University, Qingdao, Shandong 266003, P.R. China
}

Received March 5, 2015; Accepted December 15, 2015

DOI: $10.3892 / \mathrm{mmr} .2016 .4812$

\begin{abstract}
Ultraviolet (UV) radiation is considered to be a potent cell-damaging agent in various cell lineages; however, the effect of UV light-emitting diode (LED) irradiation on human cells remains unclear. The aim of the present study was to examine the effect of UV LED irradiation emitting at $280 \mathrm{~nm}$ on cultured HL-60 human leukemia cells, and to explore the underlying mechanisms. HL-60 cells were irradiated with $\operatorname{UVLED}\left(8,15,30\right.$ and $\left.60 \mathrm{~J} / \mathrm{m}^{2}\right)$ and incubated for $2 \mathrm{~h}$ after irradiation. The rates of cell proliferation and apoptosis, the cell cycle profiles and the mRNA expression of B-cell lymphoma $2(\mathrm{Bcl}-2)$ were detected using cell counting kit-8, multicaspase assays, propidium iodide staining and reverse transcription-quantitative polymerase chain reaction, respectively. The results showed that UV LED irradiation $\left(8-60 \mathrm{~J} / \mathrm{m}^{2}\right)$ inhibited the proliferation of HL-60 cells in a dose-dependent manner. UV LED at 8-30 J/m² induced dose-dependent apoptosis and G0/G1 cell cycle arrest, and inhibited the expression of $\mathrm{Bcl}-2 \mathrm{mRNA}$, while UV LED at $60 \mathrm{~J} / \mathrm{m}^{2}$ induced necrosis. In conclusion, $280 \mathrm{~nm}$ UV LED irradiation inhibits proliferation and induces apoptosis and necrosis in cultured HL-60 cells. In addition, the cell cycle arrest at the G0/G1 phase and the downregulation of $\mathrm{Bcl}-2 \mathrm{mRNA}$ expression were shown to be involved in UV LED-induced apoptosis.
\end{abstract}

Correspondence to: Professor Lirong Sun, Department of Pediatric Hematology, Affiliated Hospital of Qingdao University, 16 Jiangsu Road, Qingdao, Shandong 266003, P.R. China

E-mail: sunlr@vip.sina.com

Abbreviations: UV, ultraviolet; LED, light-emitting diode; CCK-8, cell counting kit-8; RT-qPCR, reverse transcription-quantitative polymerase chain reaction; ROS, reactive oxygen species; OD, optical density; SR-VAD-FMK, sulforhodamine-valyl-alanyl -aspartyl-fluoromethyl-ketone; 7-AAD, 7-amino-actinomycin D

Key words: ultraviolet radiation, light-emitting diode, HL-60 cells, apoptosis, necrosis

\section{Introduction}

Ultraviolet (UV) radiation is considered a potent agent for the induction of cell death (1). It has been reported that short periods of UVB irradiation trigger apoptosis, whereas prolonged exposure induces necrosis in various cell lines, including HL-60 cell lines, in vitro (2). UV-induced apoptosis is principally attributed to DNA damage, death receptor activation and reactive oxygen species (ROS) generation. These initiate multiple signaling pathways, which result in tumor suppressor gene $p 53$ activation, regulation of Bcl-2 family members and mitochondrial cytochrome $c$ release (3-6).

Traditional UV lamps have gained popularity in curing and disinfection applications for decades; however, due to high energy demand and toxicity of mercury, other sources of UV light are receiving more interest (7). Over the past few decades, UV light-emitting diodes (LEDs) have received considerable attention as an alternative UV source, due to a number of advantages over the traditional UV lamps, including the absence of mercury, high energy efficiency, increased operational flexibility and lifetime, and the absence of the requirement of a warm-up period $(8,9)$. UV LEDs have consequently been recommended to replace traditional UV lamps for numerous applications, such as sterilization, water purification and medical treatment, including medical phototherapy for plaque-type psoriasis $(10,11)$; however, the effect of UV LED irradiation on human cells remains poorly-defined. In the present study, the effect of $280 \mathrm{~nm}$ UV LED irradiation on cultured HL-60 human leukemia cells and the underlying mechanisms were examined.

\section{Materials and methods}

Cell culture. HL-60 cells were obtained from the American Type Culture Collection (Manassas, VA, USA) and cultured in Iscove's modified Dulbecco's medium (Hyclone, Logan, UT, USA) supplemented with $10 \%$ fetal bovine serum (Hyclone) in a humidified incubator with $5 \% \mathrm{CO}_{2}$ at $37^{\circ} \mathrm{C}$. Cells were passaged three times weekly, and exponentially growing cells were used for the experiments. All experiments were performed in triplicate and repeated three times. 
A

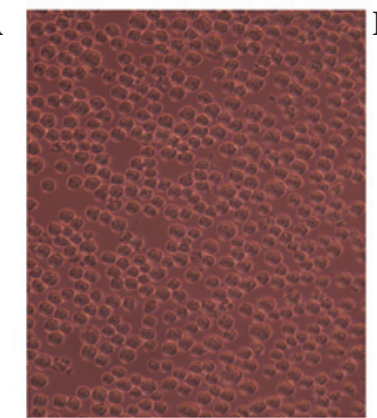

D

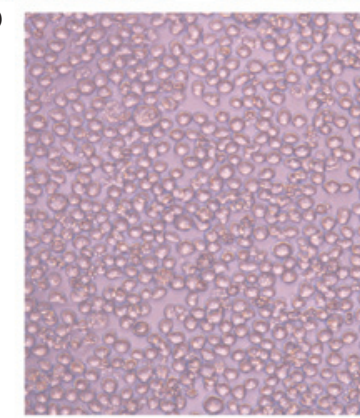

B

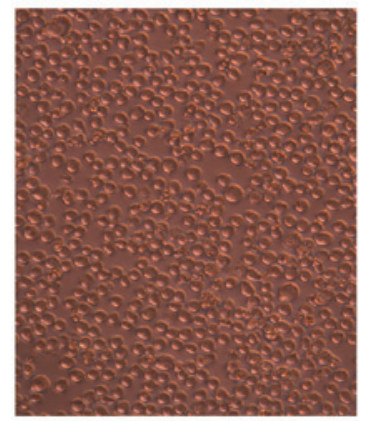

$\mathbf{E}$

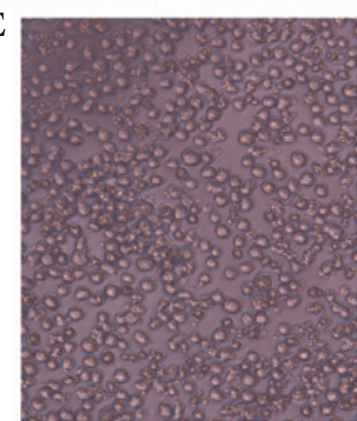

Figure 1. Morphological characteristics of cultured HL-60 cells. HL-60 cells were irradiated with (A) 0 , (B) 8 , (C) 15 , (D) 30 and (E) $60 \mathrm{~J} / \mathrm{m}^{2}$ ultraviolet light-emitting diode irradiation and incubated for $2 \mathrm{~h}$. Magnification, x200.

Cell morphology. HL-60 cells were planted in a 24-well plate at a density of $1 \times 10^{6}$ cells/well. Once cells settled to an even monolayer, they were irradiated with UV LED at $0,8,15,30$ and $60 \mathrm{~J} / \mathrm{m}^{2}$, and incubated for $2 \mathrm{~h}$ at $37^{\circ} \mathrm{C}$ in humidified air with $5 \%$ $\mathrm{CO}_{2}$. Cell morphology was observed using inverted microscopy (CKX41; Olympus Corporation, Tokyo, Japan) to identify the biological characteristics of HL-60 cells.

Cell proliferation assay. HL-60 cells were planted in a 96-well plate at a density of $4 \times 10^{4}$ cells/well. After cells had settled to an even monolayer, they were irradiated with UV LED at $0,8,15$, 30 and $60 \mathrm{~J} / \mathrm{m}^{2}$ and maintained in the $\mathrm{CO}_{2}$ incubator for $2 \mathrm{~h}$ after irradiation. All samples were co-cultured with cell counting kit-8 (CCK-8) solution (Dojindo Molecular Technologies, Inc., Kyushu, Japan) for $3 \mathrm{~h}$ before the optical density (OD) was measured at a wavelength of $450 \mathrm{~nm}$ using a microplate reader (Multiskan FC; Thermo Fisher Scientific Inc., Waltham, MA, USA). The cell viability was calculated using the following formula: Cell viability (\%) = OD 450 $0_{\text {Test }} / \mathrm{OD} 450_{\text {Control }}$ x 100 .

Flow cytometric analysis for the detection of cell death. HL-60 cell death was detected by flow cytometry (FC 500 MPL; Beckman Coulter Inc., Fullerton, CA, USA) using multicaspase assay kits (Guava Technologies, Burlingame, CA, USA). HL-60 cells were planted in a 24 -well plate at a density of $1 \times 10^{6}$ cells/well and irradiated with UV LED at 0 , $8,15,30$ and $60 \mathrm{~J} / \mathrm{m}^{2}$. Following incubation for $2 \mathrm{~h}$ at $37^{\circ} \mathrm{C}$, the cells were harvested, washed with phosphate-buffered saline (PBS) and stained with sulforhodamine-valyl -alanyl-aspartyl-fluoromethyl-ketone (SR-VAD-FMK) and 7-amino-actinomycin D (7-AAD), according to the manufacturer's protocol. SR-VAD-FMK is a caspase inhibitor that covalently binds to multiple active caspases during apoptosis, and 7-AAD is a nucleotide stain that only stains cells when membrane integrity is compromised. A total of $5 \times 10^{3}$ cells per

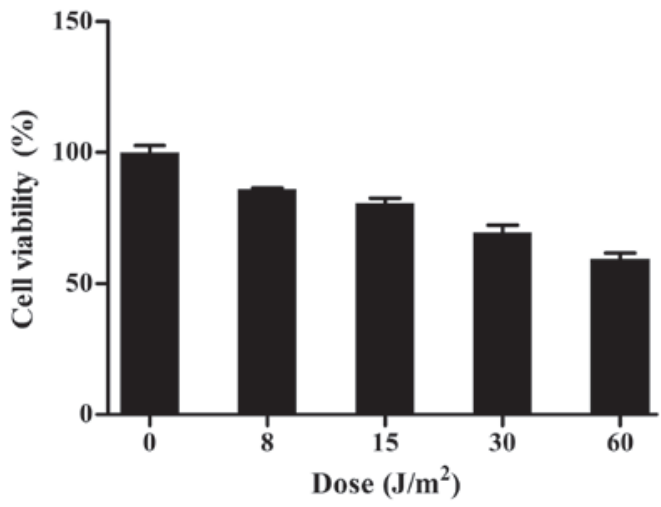

Figure 2. Ultraviolet light-emitting diode irradiation inhibits the proliferation of HL- 60 cells in a dose-dependent manner. $\mathrm{P}<0.05$ for all pairwise comparisons.

analysis were examined using flow cytometry. Unstained cells, cells stained with SR-VAD-FMK alone and cells stained with 7-AAD alone were used as controls to set up compensation and quadrants. SR-VAD-FMK positive/7-AAD negative cells (early apoptosis) and double positive cells (late apoptosis) were considered as the apoptotic cell population, while SR-VAD-FMK negative/7-AAD positive cells as the necrotic cell population.

Cell cycle analysis. HL-60 cells were plated in a 24-well plate at a density of $1 \times 10^{6}$ cells/well and exposed to UV LED irradiation at $0,8,15$ and $30 \mathrm{~J} / \mathrm{m}^{2}$. Following incubation for $2 \mathrm{~h}$, cells were harvested and resuspended in PBS and fixed in $70 \%$ ethanol at $4^{\circ} \mathrm{C}$ overnight. They were then washed twice in cold PBS and incubated with propidium iodide staining solution (Beyotime Institute of Biotechnology, Haimen, China) for $30 \mathrm{~min}$ at room temperature. The percentage of cells at various phases of the cell cycle, namely the G0/G1, S and G2/M phases, were determined by flow cytometric analysis of $1 \times 10^{5}$ cells. 

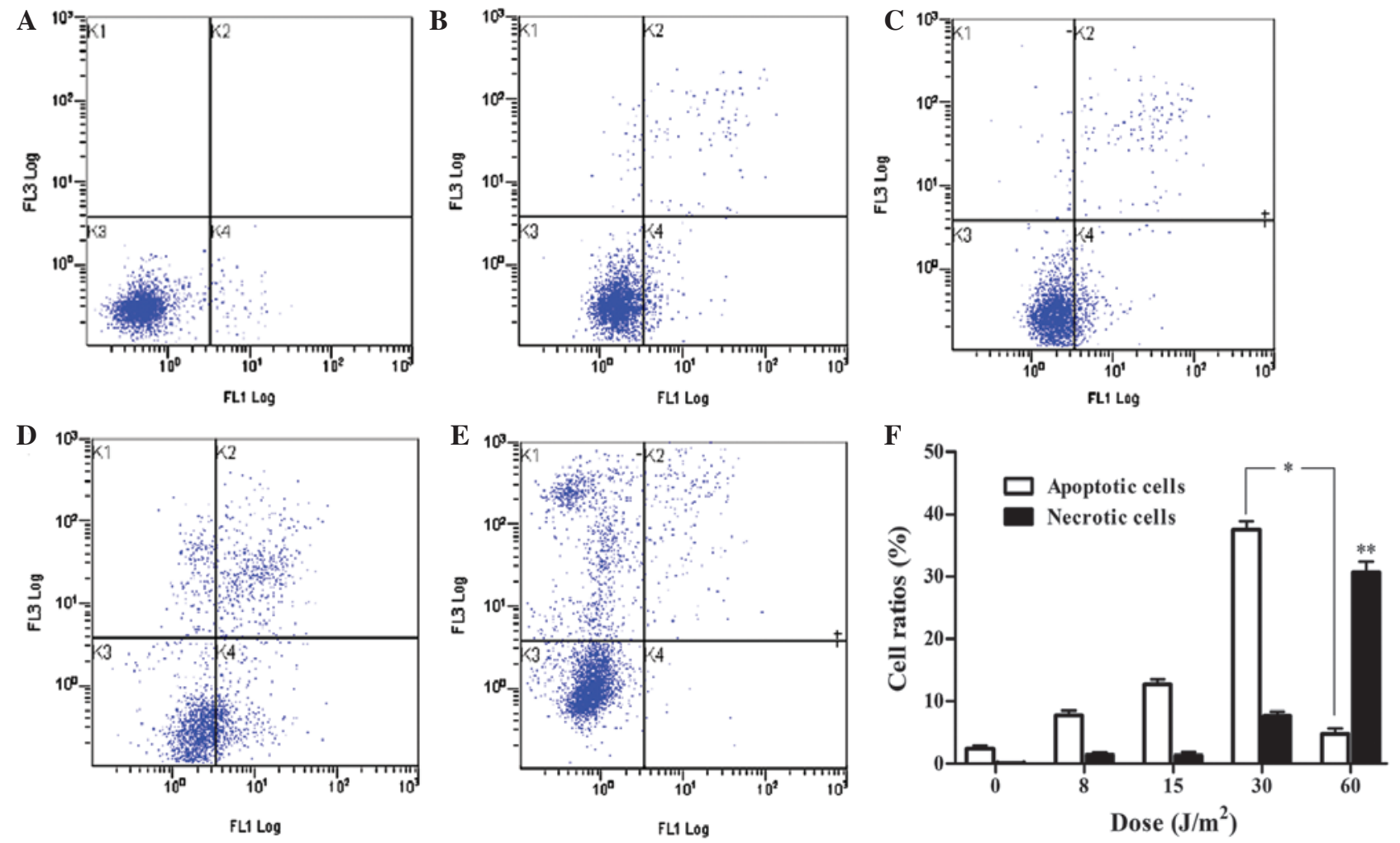

Figure 3. UV LED irradiation induces apoptotic and necrotic death in HL-60 cells. HL-60 cells were irradiated with (A) 0, (B) 8, (C) 15 , (D) 30 and (E) $60 \mathrm{~J} / \mathrm{m}^{2}$ and incubated for $2 \mathrm{~h}$. The four quadrants show the following: Lower left, viable cells; lower right, early apoptotic cells; upper right, late apoptotic cells; upper left, necrotic cells. (F) Percentage of apoptotic and necrotic HL-60 cells exposed to UV LED irradiation. P $<0.01$ for multiple pairwise comparisons of apoptotic rate within the range of $0-30 \mathrm{~J} / \mathrm{m}^{2} .{ }^{*} \mathrm{P}<0.01 \mathrm{vs.} 30$ and $60 \mathrm{~J} / \mathrm{m}^{2} ;{ }^{* *} \mathrm{P}<0.01 \mathrm{vs} .0,8,15$ and $30 \mathrm{~J} / \mathrm{m}^{2}$. UV LED, ultraviolet light-emitting diode irradiation.

Reverse transcription-quantitative polymerase chain reaction $(R T-q P C R)$. HL-60 cells were plated in a 24-well plate at a density of $1 \times 10^{6}$ cells/well and exposed to UV LED irradiation $\left(0,8,15\right.$ and $\left.30 \mathrm{~J} / \mathrm{m}^{2}\right)$. Following incubation for $2 \mathrm{~h}$, total RNA was extracted from cells using RNAiso Plus (Takara Bio, Inc., Shiga, Japan), according to the manufacturer's protocol, and quantified by OD 260/280 ratio using a NanoDrop 2000C spectrophotometer (Thermo Fisher Scientific Inc., Wilmington, DE, USA). Approximately $1 \mu \mathrm{g}$ total RNA was reverse transcribed into cDNA in a total volume of $20 \mu \mathrm{l}$ using PrimeScript ${ }^{\mathrm{TM}} \mathrm{RT}$ reagent kit with gDNA Eraser (Takara Bio, Inc.). The final $20 \mu \mathrm{l}$ PCR reaction mixture consisted of $10 \mu \mathrm{l}$ of $2 \mathrm{X}$ SYBR Premix Ex Taq (Takara Bio, Inc.), $0.8 \mu 1$ PCR Forward Primer $(10 \mu \mathrm{M})$, $0.8 \mu \mathrm{l}$ PCR Reverse Primer $(10 \mu \mathrm{M}), 2.0 \mu \mathrm{l}$ template ( $\leq 100 \mathrm{ng})$ and $6.4 \mu \mathrm{l}$ sterile distilled water. RT-qPCR was performed in a Rotor-Gene RG-3000 cycler (Qiagen Pty, Ltd., Melbourne, Australia) under the following conditions: $1 \mathrm{Cycle}$ at $95^{\circ} \mathrm{C}$ for $30 \mathrm{sec}, 40$ cycles at $95^{\circ} \mathrm{C}$ for $5 \mathrm{sec}$ and $60^{\circ} \mathrm{C}$ for $20 \mathrm{sec}$. Glyceraldehyde 3-phosphate dehydrogenase $(G A P D H)$ was used as an internal control. The relative mRNA expression of $B c l-2$ was calculated by comparing their $\mathrm{Cq}$ values with those of $G A P D H$ using the $2^{-\triangle \Delta C q}$ method (12). Statistical analysis of $\mathrm{Bcl}$-2 mRNA expression was performed using one-way analysis of variance (ANOVA), followed by the Bonferroni correction for multiple pairwise comparisons. The primer sequences used were as follows: Forward, 5'-GTCCCATCA AAACTCCTGTCTT-3' and reverse, 5'-TTTCCATCCGTC TGCTCTTC-3' for $B c l$-2; and forward, 5'-TCATGGGTGTGA ACCATGAGAA-3' and reverse, 5'-GGCATGGACTGTGGT
CATGAG-3' for GAPDH (Sangon Biotech Shanghai Co., Ltd., Shanghai, China).

Statistical analysis. Statistical analysis was conducted using SPSS 17.0 software (SPSS, Inc., Chicago, IL, USA). Comparisons among groups were performed using one-way ANOVA, followed by the Bonferroni correction for multiple pairwise comparisons. Data are presented as the mean \pm standard deviation. $\mathrm{P}<0.05$ was considered to indicate a statistically significant difference.

\section{Results}

Cell morphology. Cell morphology was observed by microscopy to identify the biological characteristics of HL-60 cells. The control cells had a smooth membrane and were round and translucent, arranged in an orderly manner, while the cells treated with UV LED (Qingdao Ziyuan Photoelectronic Co., Ltd., Qingdao, China) were found to be deformed and disordered. In addition, the transmittance and density decreased as the dose of UV LED increased. When the dose increased to $60 \mathrm{~J} / \mathrm{m}^{2}$, swollen cells and cell debris were clearly observed in the medium (Fig. 1).

UV LED irradiation inhibits the proliferation of HL-60 cells. The CCK-8 assay showed that, compared with the control group, various doses of UV LED irradiation $\left(8-60 \mathrm{~J} / \mathrm{m}^{2}\right.$ ) inhibited the proliferation of HL-60 cells in a dose-dependent manner (Fig. 2). 

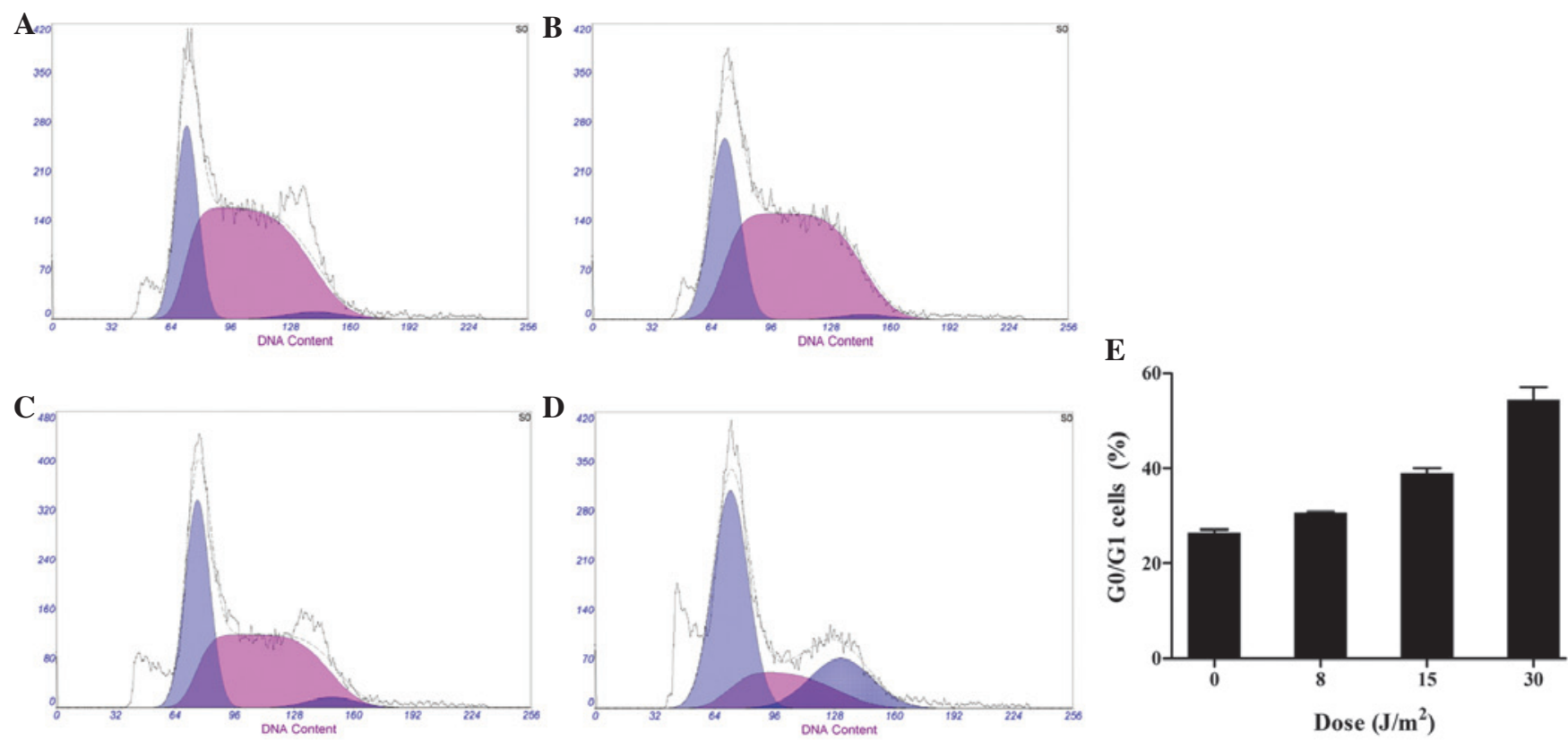

Figure 4. Cell cycle analysis of HL-60 cells determined by flow cytometry. HL-60 cells were irradiated with (A) 0 , (B) 8 , (C) 15 and (D) $30 \mathrm{~J} / \mathrm{m}^{2}$, and incubated for $2 \mathrm{~h}$. The percentages of HL-60 cells in the G0/G1 phase were 27.18, 30.74, 38.23 and 54.72\%, respectively. (E) UV LED irradiation induces dose-dependent G0/G1 arrest of HL-60 cells. P $<0.05$ for multiple pairwise comparisons.

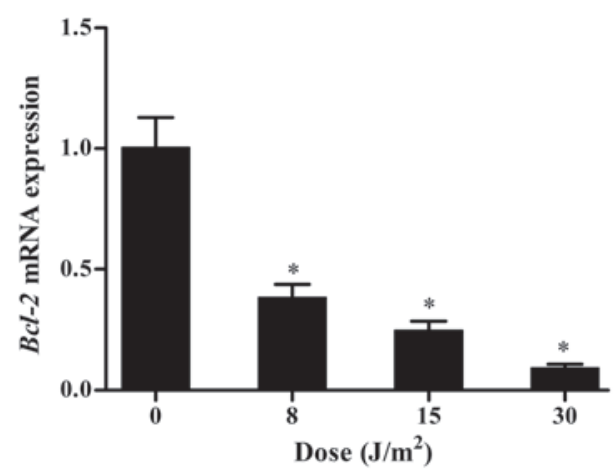

Figure 5. UV LED irradiation induces dose-dependent inhibition of the mRNA expression of $B c l-2$. The relative mRNA expression of $B c l-2$ was compared with that of untreated cells (taken as 1$)$. ${ }^{*} \mathrm{P}<0.01$ vs. the control group. UV LED, ultraviolet light-emitting diode irradiation.

UV LED irradiation induces apoptotic and necrotic death of $H L-60$ cells. To understand the mechanism of the anti-proliferative effects of UV LED irradiation on HL-60 cells, flow cytometric analysis was performed using SR-VAD-FMK/7-AAD double staining (Guava Technologies). The apoptotic cell ratios gradually increased with the increase in dose (from 8 to $30 \mathrm{~J} / \mathrm{m}^{2}$ ), indicating that UV LED at $8-30 \mathrm{~J} / \mathrm{m}^{2}$ could induce apoptosis in a dose-dependent manner. However, when cells were exposed to $60 \mathrm{~J} / \mathrm{m}^{2} \mathrm{UV}$ LED irradiation, the necrotic cell ratio markedly increased, which demonstrated that UV LED at $60 \mathrm{~J} / \mathrm{m}^{2}$ principally induced necrosis rather than apoptosis (Fig. 3).

UV LED irradiation induces cell cycle arrest of HL-60 cells. In an attempt to elucidate the mechanism underlying the induction of apoptosis by UV LED irradiation, cell cycle analysis was performed using flow cytometry. The percentages of HL-60 cells in the $\mathrm{G} 0 / \mathrm{G} 1$ phase were $27.18,30.74,38.23$ and $54.72 \%$ when cells were subjected to $0,8,5$ and $30 \mathrm{~J} / \mathrm{m}^{2} \mathrm{UV}$ LED irradiation, respectively. A dose-dependent increase was observed in the percentage of G0/G1 cells at $8-30 \mathrm{~J} / \mathrm{m}^{2}$, indicating that UV LED irradiation was capable of inducing cell cycle arrest at the G0/G1 phase (Fig. 4).

UV LED irradiation inhibits the mRNA expression of Bcl-2. In order to further examine the induction of apoptosis the mRNA expression of $B c l-2$ was detected by RT-qPCR. The results showed a decrease in the mRNA expression of $\mathrm{Bcl}-2$ at $8-30 \mathrm{~J} / \mathrm{m}^{2}$, suggesting that UV LED irradiation was able to downregulate the mRNA expression of Bcl-2 (Fig. 5).

\section{Discussion}

UV radiation has been confirmed to induce apoptosis through two biochemically and morphologically distinct processes, apoptosis and necrosis (2). Morphological features and chromatin changes show that various cell lines undergo apoptosis following low doses of UVB irradiation, whereas prolonged exposure induces necrosis (1). UV-induced apoptosis is a complex event that involves multiple pathways. UV radiation primarily induces DNA damage via the formation of ROS and DNA photoproducts, predominantly cyclobutane pyrimidine dimers and pyrimidine-pyrimidone photoproducts, that effectively block replication and transcription mechanisms $(4-6,13)$. This results in $p 53$ activation which either arrests the cell cycle to enable DNA repair or triggers apoptosis $(4,14-17)$. Although DNA damage appears to be the main cause of the induction of apoptosis $(18,19)$, it has been reported that UV radiation can either directly trigger clustering of death receptors in a ligand-independent manner, or induce the release of their natural ligands $(20,21)$. Furthermore, UV-induced ROS are able to directly cause early cytochrome $c$ release due to the mitochondrial membrane alterations, contributing independently to the induction of apoptosis (22). 
UV LEDs have become a viable option for the replacement of conventional mercury lamps for water disinfection (10). Despite the fact that UV LEDs are efficient in the destruction of microorganisms, the effect of UV LED irradiation on human cells remains to be elucidated. In the present study, it was found that $280 \mathrm{~nm}$ UV LED irradiation inhibited the proliferation of HL-60 cells in vitro. UV LED irradiation at doses between $8-30 \mathrm{~J} / \mathrm{m}^{2}$ was found to induce dose-dependent apoptosis. However, a higher dose of UV LED $\left(60 \mathrm{~J} / \mathrm{m}^{2}\right)$ was found to induce necrosis, indicating the toxic effect of UV LED irradiation at a high dose.

In response to UV-mediated DNA damage, the cell cycle is arrested and repair mechanisms, such as nucleotide excision repair, are activated (23). The presence of checkpoints allows cells to accomplish DNA repair prior to DNA synthesis or mitosis, thus reducing the incidence of DNA mutations; however, if DNA damage is extensive and irreparable, proapoptotic genes are targeted by $p 53$ to initiate mitochondrial- and death receptor-mediated apoptotic pathways, which ultimately activate a cascade of caspases to execute apoptosis (24). The present results showed that HL-60 cells underwent apoptosis and $\mathrm{G} 0 / \mathrm{G} 1$ arrest when they were subjected to $8-30 \mathrm{~J} / \mathrm{m}^{2}$ UV LED irradiation, indicating that apoptosis occurred when the cell entered the G1/S checkpoint with damaged DNA.

$B c l-2$ serves an important role in the maintenance of mitochondrial membrane potential and calcium homeostasis, in the blockage of Bax and Bak activation, and in ROS generation, thus it acts as an antiapoptotic gene (25-27). In the present study, UV LED irradiation at $8-30 \mathrm{~J} / \mathrm{m}^{2}$ induced apoptosis and inhibited the mRNA expression of $\mathrm{Bcl}$-2. This suggested that the proapoptotic effect of UV LED irradiation on HL-60 cells was associated with the downregulation of $B c l-2$ mRNA expression.

In conclusion, $280 \mathrm{~nm}$ UV LED irradiation inhibits proliferation and induces apoptosis and necrosis in cultured HL-60 human leukemia cells. G0/G1 cell cycle arrest and downregulation of the mRNA expression of $B c l-2$ are mechanisms partially responsible for the occurrence of apoptosis. Further research on other mechanisms is required in order to increase understanding of the interplay between different apoptotic pathways. This may provide an alternative way to enhance the killing effect on tumor cells.

\section{Acknowledgements}

The authors thank Dr Lingling Cui from the Gout Laboratory of the Affiliated Hospital of Qingdao University and Dr Ke Lei from the Institute of Pediatrics of Affiliated Hospital of Qingdao University for their technical assistance in the study.

\section{References}

1. Salucci S, Burattini S, Battistelli M, Baldassarri V, Maltarello MC and Falcieri E: Ultraviolet B (UVB) irradiation-induced apoptosis in various cell lineages in vitro. Int J Mol Sci 14: 532-546, 2012.

2. Martin SJ and Cotter TG: Ultraviolet B irradiation of human leukaemia HL-60 cells in vitro induces apoptosis. Int J Radiat Biol 59: 1001-1016, 1991.

3. Kulms D, Zeise E, Pöppelmann B and Schwarz T: DNA damage, death receptor activation and reactive oxygen species contribute to ultraviolet radiation-induced apoptosis in an essential and independent way. Oncogene 21: 5844-5851, 2002.
4. Kulms D and Schwarz T: Molecular mechanisms of UV-induced apoptosis. Photodermatol Photoimmunol Photomed 16: 195-201, 2000.

5. Timares L, Katiyar SK and Elmets CA: DNA damage, apoptosis and langerhans cells-activators of UV-induced immune tolerance. Photochem Photobiol 84: 422-436, 2008.

6. Liang YG, Jorgensen AG, Kaestel CG, Wiencke AK, Lui GM, la Cour MH, Röpke CH and Nissen MH: Bcl-2, Bax and c-Fos expression correlates to RPE cell apoptosis induced by UV-light and daunorubicin. Current Eye Res 20: 25-34, 2000.

7. Crawford MH, Banas MA, Ross MP, Ruby DS, Nelson JS, Boucher R and Allerman AA. Final LDRD report: ultraviolet water purification systems for rural environments and mobile applications. Sandia Report: 1-35, 2005.

8. Würtele MA, Kolbe T, Lipsz M, Külberg A, Weyers M, Kneissl M and Jekel M: Application of GaN-based ultraviolet-C light emitting diodes-UV LEDs-for water disinfection. Water Res 45: 1481-1489, 2011.

9. Chatterley $\mathrm{C}$ and Linden K: Demonstration and evaluation of germicidal UV-LEDs for point-of-use water disinfection. J Water Health 8: 479-486, 2010.

10. Vilhunen S, Särkkä H and Sillanpää M: Ultraviolet light-emitting diodes in water disinfection. Environ Sci Pollut Res Int 16: 439-442, 2009.

11. Kemeny L, Csoma Z, Bagdi E, Banham AH, Krenacs L and Koreck A: Targeted phototherapy of plaque-type psoriasis using ultraviolet B-light-emitting diodes. Br J Dermatol 163: 167-173, 2010.

12. Proietti De Santis L, Garcia CL, Balajee AS, Latini P, Pichierri P, Nikaido O, Stefanini M and Palitti F: Transcription coupled repair efficiency determines the cell cycle progression and apoptosis after UV exposure in hamster cells. DNA Repair (Amst) 1: 209-223, 2002.

13. Livak KJ and Schmittgen TD: Analysis of relative gene expression data using real-time quantitative PCR and the 2(-Delta Delta C(T)) Method. Methods 25: 402-408, 2001.

14. Ravanat JL, Douki T and Cadet J: Direct and indirect effects of UV radiation on DNA and its components. J Photochem Photobiol B 63: 88-102, 2001.

15. Murphy G, Young AR, Wulf HC, Kulms D and Schwarz T: The molecular determinants of sunburn cell formation. Exp Dermatol 10: 155-160, 2001.

16. Cadet J, Sage E and Douki T: Ultraviolet radiation-mediated damage to cellular DNA. Mutat Res 571: 3-17, 2005.

17. Pattison DI and Davies MJ: Actions of ultraviolet light on cellular structures. EXS: 131-157, 2006.

18. Dunkern TR, Fritz G and Kaina B: Ultraviolet light-induced DNA damage triggers apoptosis in nucleotide excision repair-deficient cells via Bcl-2 decline and caspase-3/-8 activation. Oncogene 20: 6026-6038, 2001.

19. Stege H, Roza L, Vink AA, Grewe M, Ruzicka T, Grether-Beck S and Krutmann J: Enzyme plus light therapy to repair DNA damage in ultraviolet-B-irradiated human skin. Proc Natl Acad Sci USA 97: 1790-1795, 2000.

20. Zhuang S and Kochevar IE: Ultraviolet A radiation induces rapid apoptosis of human leukemia cells by Fas ligand-independent activation of the Fas death pathways. Photochem Photobiol 78: 61-67, 2003.

21. Bang B, Gniadecki R, Larsen JK, Baadsgaard O and Skov L: In vivo UVB irradiation induces clustering of Fas (CD95) on human epidermal cells. Exp Dermatol 12: 791-798, 2003.

22. Ali D, Verma A, Mujtaba F, Dwivedi A, Hans RK and Ray RS: UVB-induced apoptosis and DNA damaging potential of chrysene via reactive oxygen species in human keratinocytes. Toxicol Lett 204: 199-207, 2011.

23. Costa RM, Chiganças V, Galhardo Rda S, Carvalho H and Menck CF: The eukaryotic nucleotide excision repair pathway. Biochimie 85: 1083-1099, 2003.

24. Benchimol S: p53-dependent pathways of apoptosis. Cell Death Differ 8: 1049-1051, 2001.

25. Rizzuto R, Pinton P, Ferrari D, Chami M, Szabadkai G, Magalhães PJ, Di Virgilio F and Pozzan T: Calcium and apoptosis: Facts and hypotheses. Oncogene 22: 8619-8627, 2003.

26. Adams JM and Cory S: Life-or-death decisions by the Bcl-2 protein family. Trends Biochem Sci 26: 61-66, 2001.

27. Assefa Z, Garmyn M, Vantieghem A, Declercq W, Vandenabeele P, Vandenheede JR and Agostinis P: Ultraviolet B radiation-induced apoptosis in human keratinocytes: Cytosolic activation of procaspase- 8 and the role of Bcl-2. FEBS Lett 540: 125-132, 2003. 